\title{
Disability Self-evaluation for Low Back Pain in COVID-19 Pandemic
}

\author{
Listya Tresnanti Mirtha1, Diandra Amandita Priambodo², Dinda Nisrina², \\ Evita Stephanie $^{2}$, Kharisma Zatalini Giyani ${ }^{2}$
}

${ }^{1}$ Community Medicine Department, Faculty of Medicine, Universitas Indonesia, Jakarta, Indonesia ${ }^{2}$ Faculty of Medicine, Universitas Indonesia, Jakarta, Indonesia

\begin{abstract}
Introduction: Low back pain (LBP) interferes with daily activities, which is why monitoring of functional disability is important. Non-urgent hospital visits are reduced due to the COVID-19 pandemic. Functional disability questionnaires serve as an alternative for patients to self-monitor their condition.

Methods: This case-based study aimed to compare the Quebec Back Pain Disability Scale (QBPDS) with the Oswestry Disability Index (ODI) on their responsiveness in assessing functional disability of patients with LBP. Four databases (PubMed, Scopus, Cochrane, and Embase) were searched for literature. Two eligible studies were included in this report. The studies were assessed using the Centre for EvidenceBased Medicine critical appraisal tool for diagnostic studies. Data collected on the responsiveness of ODI and QBPDS were measured using the area under the curve (AUC) of a receiver operating curve (ROC), sensitivity, and specificity.
\end{abstract}

Result: Both studies reported higher AUC values for ODI than QBPDS. One study reported higher sensitivity in ODI and identical specificity values for both ODI and QBPDS. QBPDS has comparable responsiveness to ODI in assessing functional disability of patients with LBP.

Conclusion: Therefore, patients with low back pain can self-monitor their condition with QPBDS, as it is comparable to ODI and suitable for self-monitor during the COVID-19 pandemic

Keywords: assessment, disability evaluation, low back pain, musculoskeletal pain, surveys and questionnaires 
ABSTRAK

Latar belakang: Nyeri punggung bawah (NPB) dapat mengganggu kegiatan sehari-hari, oleh karena itu pemantauan disabilitas fungsional menjadi penting. Kunjungan ke rumah sakit yang bersifat tidak mendesak berkurang selama pandemi COVID-19.

Metode: Kuesioner yang membahas disabilitas fungsional dapat dijadikan sebagai alternatif untuk memantau sendiri kondisinya. Studi berbasis kasus ini mempunyai tujuan untuk membandingkan Quebec Back Pain Disability Scale (QBPDS) dengan kuesioner Oswestry Disability Index (ODI) terhadap responsivitas dalam menilai disabilitas fungsional pada pasien NPB. Pencarian pada empat database (PubMed, Scopus, Cochrane, and Embase) dilakukan untuk mencari literatur. Dua studi memenuhi kriteria dan dibahas dalam laporan ini. Studi dinilai menggunakan pedoman telaah kritis Centre for Evidence-Based Medicine untuk studi diagnostik. Data yang dikumpulkan adalah responsivitas ODI dan QBPDS yang diukur menggunakan area under curve $(A U C)$ dari receiver operating curve (ROC), sensitivitas, dan spesifisitas.

Hasil: Dua studi tersebut melaporkan nilai $A U C$ yang lebih tinggi dibandingkan dengan QBPDS. Satu studi menyatakan sensitivitas yang lebih tinggi pada ODI dan nilai spesifisitas yang serupa antara ODI dan QBPDS. QBPDS memiliki nilai responsivitas yang sama dalam menilai disabilitas fungsional pada pasien dengan NPB.

Kesimpulan: Pasien dengan nyeri punggung bawah dapat menggunakan QBPDS untuk memantau kondisi keluhannya, karena sebanding dengan ODI dan cocok untuk pemantauan yang dilakukan di rumah di masa pandemi COVID-19.

Kata kunci: evaluasi disabilitas; nyeri punggung bawah, nyeri mukuloskeletal, penilaian, survei dan kuesioner.

\section{Correspondent Detail:}

\section{Listya Tresnanti Mirtha}

Email: tresnanti.listya@ui.ac.id

Community Medicine Department, Faculty of Medicine, Universitas Indonesia, Jakarta, Indonesia

\section{INTRODUCTION}

Countries around the world are implementing various measures in facing the COVID-19 pandemic. To control the spreading and number of COVID-19 cases, the world is facing a major alteration in its everyday life. Social distancing measures, traveling restrictions, and staying at home are now a part of our "new normal" life. ${ }^{1}$ The Indonesian government implemented a large-scale social distancing scheme within the country, especially Jakarta which had become one of the epicentrum of COVID-19 in Indonesia. The large-scale social distancing schemes obligated schools and work to be done remotely from home and minimized activities in public places. This resulted in an increased time at home and increased sedentary behaviors among the people since many opportunities to be physically active have been suspended. ${ }^{1-2}$ Given the change in daily life for people around the world as a result of the pandemic, this health crisis has the potential 
to further impact and accelerate widespread physical inactivity and sedentary behavior that we are confronted with and have been failing to address for many years.

Low back pain (LBP) is one of the most common musculoskeletal problems affecting the adult population. The point prevalence estimate of LBP ranged from $1-58 \%$ and lifetime prevalence ranged between $11-84 \%$ in low-income countries. ${ }^{3}$ Non-specific back pain is the most common type of LBP with differing etiologies depending on the patient population. Mechanical LBP is the most frequent cause, which usually arises from the spine, intervertebral disks and surrounding tissues. ${ }^{4}$ Based on duration, LBP is classified into acute ( $<4$ weeks), subacute ( 4 weeks-3 months), and chronic ( $>3$ months). LBP has a serious impact on patients' functional capacity as the pain limits daily-life and occupational activities, which affects everyday performance. ${ }^{3,5}$

Improving patients' level of participation in doing daily activities is the main concern in patients with LBP. Questionnaires are available to measure pain and classify LBP patients into different functional disability statuses/levels. Self-administered questionnaires may prove useful in the current pandemic situation since the assessment of functional disability can be done independently by the patient and their condition can be monitored without having to go to the hospital. However, a gold standard to evaluate disability in patients with LBP does not exist.

The Oswestry Disability Index (ODI) is a widely used outcome-measure questionnaire in hospital settings and is seen as a "gold standard" for assessing disability in LBP patients. As a selfadministered questionnaire published in 1980,
ODI is divided into ten sections assessing limitations of daily activities. Items are scored on a 5 -point scale $(0=$ no disability, $5=$ greatest disability). The final score ranges from 0-100, with a score of $0-20$ reflecting minimal disability, 41-60 as severe disability, $61-80$ as crippled, and $81-100$ as bed-bound. Although ODI is the widely used "gold standard" in assessing low back pain, it is mainly focused only on physical activities and does not include the psychological consequences of acute or chronic pain that may affect one's quality of life. Thus it may not have a comprehensive assessment of the patient. ${ }^{6}$

A newer well-validated questionnaire alternative to be used is the Quebec Back Pain Disability Scale (QBPDS) developed in 1995, commonly used in randomized controlled trials. This questionnaire uses a conceptual model of disability. Referring to the WHO definition, the QBPDS defined disability as difficulty in performing simple tasks. There are 20 items included in the questionnaire, where all types of physical activities relevant to back pain should be represented in movements of bed/rest, sitting/standing, ambulation, movement, bending/ stooping, and handling large/heavy objects. ${ }^{7}$ The 20-item self-administered questionnaire uses a 6-point scale ( $0=$ "not difficult at all", $5=$ "unable to do"). The total score ranges $0-100$ with higher values representing greater disability. The QBPDS has been postulated as able to give a more comprehensive assessment of LBP in patients due to its more detailed physical activities questionnaire items, as well as being a conceptual model of disability. Even with its more detailed questionnaire items, the QBPDS remains easy to use and has a low respondent burden. ${ }^{8}$

Currently, there are several questionnaires measuring activity limitation due to disability in 
LBP patients, but none are determined as the gold standard to assess functional quality outcome in LBP patients. The ODI is preferred by healthcare professionals, but the less-popular QBPDS may be more appropriate for patients to use independently at home. This Evidence-Based Case Report aims to assess the performance of QBDPS in assessing functional disability compared to ODI, as there is still little evidence comparing the responsiveness of QBPDS and ODI scales.

\section{METHODS}

\section{Clinical Scenario}

A 32-year-old patient consulted via telemedicine to monitor his low back pain. The patient's job requires him to sit behind the desk for a long time. Due to the national government's response to the COVID-19 pandemic, his sitting time is longer as he worked from home where he sat for 8-10 hours a day, where he rarely have breaks in between sitting time. He believed that this prolonged sitting time during his work from home period worsened his pain and he worried that this would affect his ability to perform daily activities since he complained of increased pain during prayers (sholat). When sitting throughout the day, his pain worsened and he experienced a feeling of numbness or tingling sensation every once in a while.
The patient asked the doctor how he could monitor his condition without having to come to the hospital if not necessary. The doctor wanted to recommend a self-administered questionnaire for the patient to do on his own at home but did not know which to choose between the Oswestry Disability Index (ODI) and the Quebec back pain disability scale (QBPDS) measurement tools. The ODI is popularly used among healthcare professionals, but the doctor has only seen it used in a hospital setting. The doctor considers the QBPDS instead, because its questionnaire items, which assess difficulty in performing simple tasks, are perhaps more appropriate for use at home. However, the QBPDS is less popular and more recently developed compared to the ODI.

This Evidence-Based Case Report, therefore, aims to answer which questionnaire is best for independent monitoring of functional disability in low back pain conditions.

\section{Search strategy}

Search for relevant literature was conducted on $2^{\text {nd }}$ November 2020 on four electronic databases: MEDLINE via PubMed, Cochrane Library, EMBASE via Ovid, and Scopus (see Table 1). Manual hand-searching for relevant studies was additionally conducted.

Table 1. Search strategy

\begin{tabular}{cccc}
\hline Database & Search strategy & Hits & Selected article \\
\hline Pubmed & ((low back pain) OR (LBP)) AND ((Quebec back pain) & 10 & 1 \\
Scopus & OR (Quebec low back pain) OR (Quebec back pain & 4 & 0 \\
Cochrane & disability scale) OR (QBPDS)) AND ((Oswestry & 1 & 0 \\
Embase & Disability Index) OR (Oswestry low back pain disability & 4 & 0 \\
& questionnaire) OR (ODI)) AND (responsiveness) & & \\
\hline
\end{tabular}




\section{Selection criteria}

Published studies that met the inclusion criteria were considered as eligible and included in this report: (i) adults (19-65 years old) diagnosed with low back pain, (ii) evaluating the responsiveness of questionnaires. Responsiveness refers to the quality of the questionnaire as an accurate tool for disability evaluation in patients with low back pain as measured using the area under the curve (AUC) of a receiver operating curve (ROC), sensitivity and specificity. Studies that met the exclusion criteria were considered ineligible for inclusion in this report: (i) adults with anatomical causes of low back pain or specific low back pain, (ii) non-English publications, and (iii) unavailable full-text.

\section{Critical appraisal tool}

Studies selected for inclusion were critically appraised using the Centre for Evidence-Based Medicine critical appraisal tool ${ }^{9}$ for diagnostic studies.

\section{RESULTS}

\section{Study selection}

The search yielded 24 records, 19 from databases and five from hand-searching. After the removal of duplicates, 16 studies were screened based on title and abstract. Nine studies were excluded for not meeting the eligibility criteria. From seven full-text articles assessed for eligibility, a total of two studies were included for the final appraisal (Figure 1).

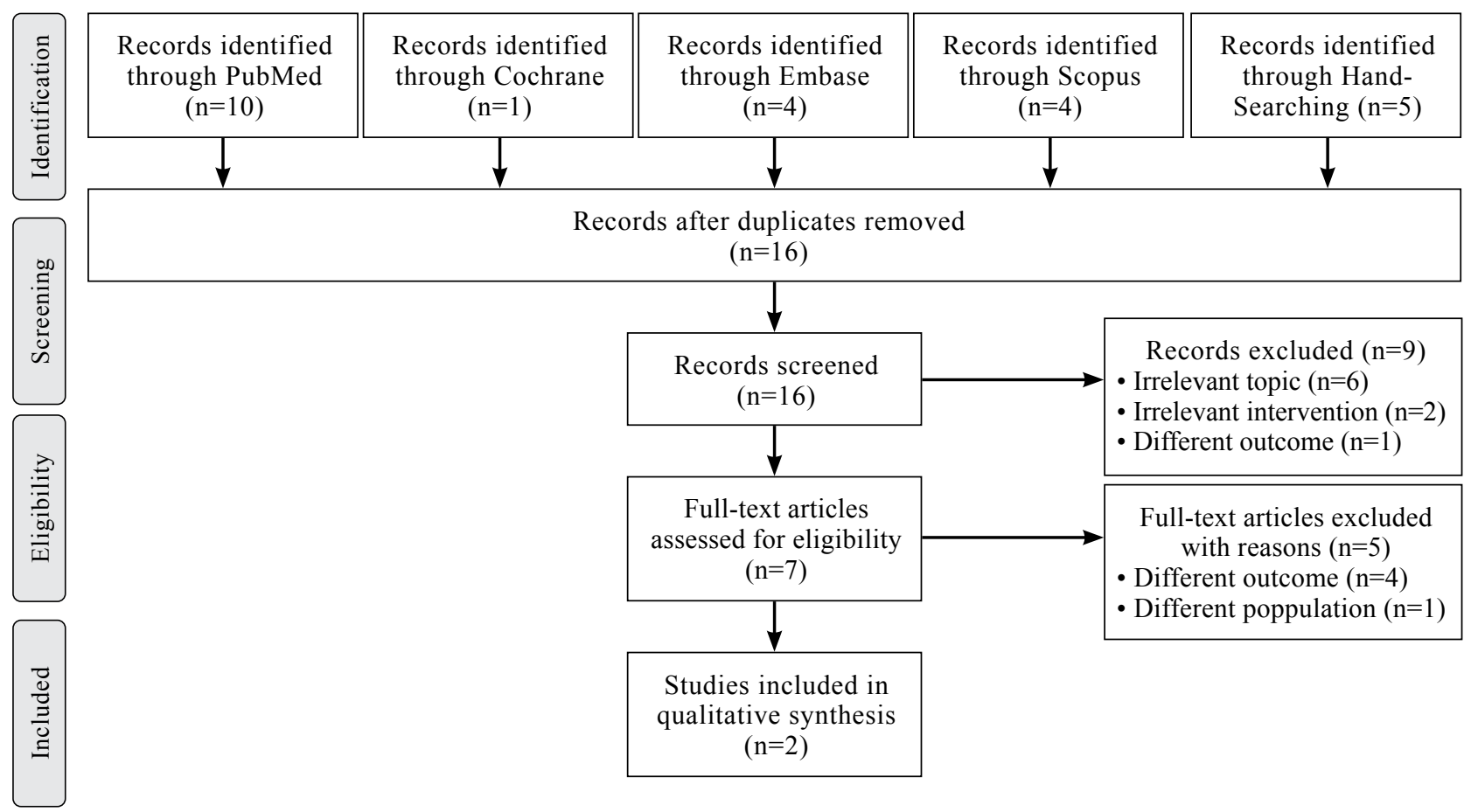

Search Date: Monday, 2 November 2020

Figure 1. Study selection based on inclusion and exclusion criteria (PRISMA 2009 Flow Diagram) ${ }^{10}$ 


\section{Study findings}

Fritz et al. ${ }^{11}$ performed a study to evaluate the measurement properties of modified ODI and QBPDS compared to the average global rating. Participants were scored on their initial and final evaluation, sensitivity and specificity were evaluated by comparing the proportion of participants with improved and stable conditions between the two scales and the average global rating. Responsiveness was evaluated by calculating sensitivity and specificity using the receiver operating characteristics (ROC) curve. They reported modified ODI to have a higher responsiveness ( $\mathrm{AUC}=0.94$ [95\%CI:0.89-0.99]) than the QBPDS questionnaire $\quad(\mathrm{AUC}=0.87 \quad$ [95\%CI:0.77$0.96])$. The sensitivity of modified ODI is higher $($ sensitivity $=91 \%$ [95\%CI:82-99\%]) than QBPDS (sensitivity:82\% [95\%CI:70\%93\%]). Specificity is identical in modified ODI and QBPDS (specificity $=83 \%$ [95\%CI:67-98\%]).
The other study in our review evaluated the responsiveness of five most commonly used low back pain disability questionnaires in detecting functional disability in patients with LBP. ${ }^{12}$ Davidson et al. ${ }^{12}$ conducted a prospective study, repeating the same questionnaire for each subject with an interval time of six weeks to test reliability and responsiveness. Subjects were classified into "unchanged" and "improved" according to their questionnaire scores. Questionnaire responsiveness was measured by whether the subjects had clinically meaningful changes. Using the area under the ROC curve, they identified the ability of each questionnaire to distinguish improved subjects from those with unchanged conditions. Responsiveness score by the area under the ROC curve demonstrated ODI with a slightly higher responsiveness $(\mathrm{AUC}=0.78$ [95\%CI:0.69-0.87]) than QBPDS (AUC $=0.74$ [95\%CI:0.64-0.84]). However, Davidson et al. did not report on the sensitivity and specificity scores for each questionnaire. See Table 2 for a summary of the key characteristics of included studies. 
Table 2. Key characteristics of the included studies

\begin{tabular}{|c|c|c|c|c|c|c|}
\hline Author & $\begin{array}{l}\text { Level of } \\
\text { evidence }\end{array}$ & $\begin{array}{l}\text { Patient } \\
\text { group }\end{array}$ & $\begin{array}{c}\text { Intervention } \\
\text { and } \\
\text { comparison }\end{array}$ & $\begin{array}{l}\text { Outcome and } \\
\text { method of } \\
\text { assessment }\end{array}$ & Key results & Comments \\
\hline $\begin{array}{l}\text { Fritz JM, } \\
\text { Irrgang JJ } \\
(2001)^{11}\end{array}$ & $\begin{array}{l}\text { Level } 2 \\
\text { (cohort } \\
\text { study) }\end{array}$ & $\begin{array}{l}67 \text { patients } \\
\text { with LBP } \\
\text { (pain on the } \\
\text { lumbosacral } \\
\text { spine) of } \\
\text { sufficient } \\
\text { magnitude to } \\
\text { necessitate a } \\
\text { modification } \\
\text { in work duties } \\
\text { and referral } \\
\text { for physical } \\
\text { therapy }\end{array}$ & $\begin{array}{l}\text { This study } \\
\text { compares the } \\
\text { measurement } \\
\text { properties of } \\
\text { QBPDS and } \\
\text { ODI }\end{array}$ & $\begin{array}{l}\text { Reliability, } \\
\text { responsiveness, } \\
\text { and statistically } \\
\text { and minimal } \\
\text { clinically } \\
\text { important } \\
\text { difference } \\
\text { (CMID) from } \\
\text { global of change, } \\
\text { based on the } \\
\text { questionnaires }\end{array}$ & $\begin{array}{l}\text { Reliability, } \\
\text { responsiveness, } \\
\text { and statistically } \\
\text { and minimal } \\
\text { clinically } \\
\text { important } \\
\text { difference } \\
\text { (CMID) } \\
\text { from global } \\
\text { of change, } \\
\text { based on the } \\
\text { questionnaires }\end{array}$ & $\begin{array}{l}\text { The study } \\
\text { explores } \\
\text { performance } \\
\text { of each } \\
\text { questionnaires } \\
\text { based on the } \\
\text { mean global } \\
\text { rating of } \\
\text { the patients, } \\
\text { although at } \\
\text { the end the } \\
\text { QBPDS was } \\
\text { compared with } \\
\text { the ODI }\end{array}$ \\
\hline $\begin{array}{l}\text { Davidson } \\
\text { M, Keating } \\
\text { JL (2002) })^{12}\end{array}$ & $\begin{array}{l}\text { Level } 2 \\
\text { (cohort } \\
\text { study) }\end{array}$ & $\begin{array}{l}106 \text { patients } \\
\text { with LBP } \\
\text { seeking } \\
\text { treatment from } \\
\text { a physical } \\
\text { therapist }\end{array}$ & $\begin{array}{l}\text { This study } \\
\text { compares the } \\
\text { measurement } \\
\text { properties of } \\
\text { five low back } \\
\text { disability } \\
\text { questionnaires, } \\
\text { including } \\
\text { QBPDS and } \\
\text { ODI }\end{array}$ & $\begin{array}{l}\text { Responsiveness } \\
\text { using } \\
\text { standardized } \\
\text { response means, } \\
\text { ROC curve, } \\
\text { and meaningful } \\
\text { detectable } \\
\text { changes (MDC) }\end{array}$ & $\begin{array}{l}\text { All five } \\
\text { questionnaires } \\
\text { have similar } \\
\text { responsiveness } \\
\text { based on } \\
\text { analyzing the } \\
\text { ROC curve }\end{array}$ & $\begin{array}{l}\text { This study } \\
\text { evaluates } \\
\text { reliability and } \\
\text { responsiveness } \\
\text { between } 5 \\
\text { commonly } \\
\text { used LBP } \\
\text { questionnaires }\end{array}$ \\
\hline
\end{tabular}

\section{Critical appraisal}

Appraisal of the study by Fritz et al. demonstrated valid methods, important results, replication applicability, and relevance to our clinical problems. However, the appraisal results of the study by Davidson et al. was inconclusive because the study had limited data that could be assessed. Independent and blind comparisons were unclear, although the study mentioned its concern about completion of questionnaires, which was unsupervised thus unknown whether subjects completed the questionnaires as intended or not. Data on sensitivity and specificity were absent and therefore could not be reported under importance. ${ }^{9,11,12}$
Positive and negative predictive values were not reported by both studies. This may be due to the nature of the questionnaires being studied that have no cut-off for positive or negative values, since the outcome of the questionnaires were to classify patients into different disability levels. For this reason, the predictive values were not applicable to be measured. ${ }^{11,12}$

See Table 3 for a summary of the critical appraisal. 
Table 3. Critical appraisal of included studies

\begin{tabular}{|c|c|c|c|c|c|c|c|c|c|c|c|c|c|}
\hline \multirow[b]{2}{*}{ Author } & \multirow[b]{2}{*}{$\begin{array}{l}\text { Level of } \\
\text { evidence }\end{array}$} & \multicolumn{3}{|c|}{ Relevance } & \multicolumn{3}{|c|}{ Validity } & \multicolumn{5}{|c|}{ Importance } & \multirow{2}{*}{$\begin{array}{c}\text { Applicability } \\
\\
\text { Methods for } \\
\text { permitting } \\
\text { replication }\end{array}$} \\
\hline & & 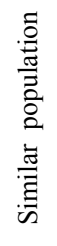 & 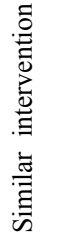 & 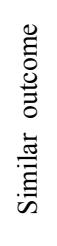 & 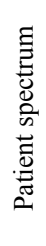 & 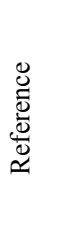 & $\stackrel{\infty}{\Xi}$ & AUC & Sensitivity & Specificity & PPV & NPV & \\
\hline \multirow[t]{2}{*}{$\begin{array}{l}\text { Fritz, et al. } \\
(2001)\end{array}$} & $\begin{array}{l}\text { Level } 2 \\
\text { (Cohort } \\
\text { study) }\end{array}$ & + & + & + & + & + & + & $\begin{array}{l}\text { QUE }= \\
0.87(95 \% \\
\text { CI } 0.77- \\
0.96)\end{array}$ & $\begin{array}{l}\text { QUE: 82\% } \\
\text { (95\% CI } \\
70-93 \%)\end{array}$ & $\begin{array}{l}\text { QUE: 83\% } \\
\text { (95\% CI } \\
67-98 \%)\end{array}$ & \multirow{2}{*}{\multicolumn{2}{|c|}{ Not applicable }} & + \\
\hline & & & & & & & & $\begin{array}{l}\mathrm{ODI}=0.94 \\
(95 \% \mathrm{CI} \\
0.89-0.99)\end{array}$ & $\begin{array}{l}\text { ODI: } 91 \% \\
(95 \% \text { CI } 82- \\
99 \%)\end{array}$ & $\begin{array}{l}\text { ODI: } 83 \% \\
(95 \% \text { CI } \\
67-98 \%)\end{array}$ & & & \\
\hline $\begin{array}{l}\text { Davidson, } \\
\text { et al. } \\
(2002)\end{array}$ & $\begin{array}{l}\text { Level } 2 \\
\text { (Cohort } \\
\text { study) }\end{array}$ & + & + & $+/-$ & + & + & - & $\begin{array}{l}\text { QUE: } 0.74 \\
(95 \% \text { CI } \\
0.64-0.84) \\
\\
\text { ODI: } 0.78 \\
(95 \% \text { CI } \\
0.69-0.87)\end{array}$ & Not available & & \multicolumn{2}{|c|}{ Not applicable } & + \\
\hline
\end{tabular}

AUC: Area under curve, PPV: Positive predictive value, NPV: Negative predictive value

\section{DISCUSSION}

Different questionnaires are available for independent monitoring of functional disability in LBP patients. Our current review compares the difference in accuracy between the ODI, a commonly used tool in hospital settings, and the QBPDS, a contending alternative. Accuracy values (AUC, sensitivity and specificity) provide a comparison of each questionnaire's responsiveness. Fritz et al. ${ }^{11}$ and Davidson et al. ${ }^{12}$ reported different values of AUC, however, both studies reported higher AUC values for ODI compared to QBPDS. Fritz et al. reported that AUC for ODI was 0.94 (95\%CI:0.89-0.99) and QBPDS was 0.87 (95\%CI:0.77-0.96). Davidson et al. reported AUC of ODI as 0.78 (95\%CI:0.69$0.87)$ and QBPDS as 0.74 (95\%CI:0.64-0.84). ${ }^{12}$

These findings suggest that ODI remains more reliable to assess functional disability compared to QBPDS. However, when taking into account the $95 \%$ confidence interval $(95 \% \mathrm{CI})$ for the AUC, there was no statistically significant difference between AUC values of ODI and QBPDS. Additionally, the 95\% CI of AUC values in both studies was wide, indicating lower precision of results. These findings suggest that the responsiveness of QBPDS as measured by AUC is comparable to ODI.

Sensitivity and specificity comparison was only available in one study. ${ }^{11}$ Fritz et al. reported ODI with a sensitivity of 91\% (95\%CI:82-99\%) and specificity of $83 \%$ (95\%CI:67-98\%). While QBPDS was reported with a sensitivity of $82 \%$ (95\% CI:70-93\%) and specificity of $83 \%$ (95\%CI:67-98\%). Davidson et al. ${ }^{12}$ did not report these values and raw data results were also not reported in neither text nor supplement, which hindered manual computations of sensitivity and specificity. 
Fritz et al. ${ }^{11}$ showed identical specificity values for ODI and QBPDS (both reported 83\% sensitivity), nevertheless, their wide 95\% CI indicates low precision. Sensitivity was reported to be higher for ODI, but overlapping 95\% CI values demonstrates that there is no statistically significant difference between the two. Consequently, based on its sensitivity and specificity values, it could be concluded that QBPDS is comparable to ODI. This comparability is further supported by the characteristic of both questionnaires. The ODI is centered around physical activities, rather than the psychological impact of back pain. Similarly, the QBPDS is a questionnaire that focused on assessing the performance of physical tasks. The focus of each questionnaire is an important aspect to consider when making comparisons.

Overall, the very limited number of available evidence comparing ODI and QBPDS has limited the discussion of the current report to only two studies. There were several limitations to the studies in the review. The discrepancy in AUC values between Fritz et al. ${ }^{11}$ and Davidson et al. ${ }^{12}$ may be attributable to their different sample sizes. Fritz et al. ${ }^{11}$ reported higher AUC value for both ODI and QBPDS compared to Davidson et al., ${ }^{12}$ but involved only 67 participants in their study. On the other hand, Davidson et al. ${ }^{12}$ involved a total of 106 participants. Furthermore, the failure of Davidson et al. ${ }^{12}$ to report on the sensitivity and specificity values for both questionnaires limited the current discussion. Raw data was not provided by the authors and therefore computation could not be conducted manually. Furthermore, the study methodology of Davidson et al. ${ }^{12}$ is liable to create bias due to its lack of blinding and unsupervised questionnaire completion by participants.
A strength of the study by Fritz et al. ${ }^{11}$ was its focus on comparing QBPDS with ODI. Davidson et al. $^{12}$ differently compared five different questionnaires, including QBPDS and ODI, which may cause its study to be relatively weaker in reporting the comparison between QBPDS and ODI.

\section{CONCLUSION}

In conclusion, QBPDS is comparable in terms of accuracy to the ODI for assessing disability in patients with LBP, thus answering the initial clinical question of this report. The findings discussed demonstrated that both questionnaires have high responsiveness as identified by the measures of AUC. We, therefore, recommend the QBPDS for patients to use and selfmonitor his low back pain at home during the COVID-19 pandemic, to minimize visits to the hospital without a clear purpose. The Indonesian version of the questionnaires can be opted if our patient is not fluent in English for an accurate result assessment. The results of self-assessment could afterward be consulted to his physician via telemedicine as a reference for future treatment and monitoring. QBPDS as a self-administered low back pain measurement tool provides patients with the benefit of selfmonitoring their condition, which is especially important with current stay-at-home restrictions during the COVID-19 pandemic.

\section{ACKNOWLEDGEMENT}

We would like to acknowledge the support, help, and feedback we received from Dr. dr. Listya Tresnanti Mirtha, Sp.KO in the course of making this report. 


\section{REFERENCES}

1. Hall G, Laddu DR, Phillips SA, Lavie CJ, Arena R. A tale of two pandemics: How will COVID-19 and global trends in physical inactivity and sedentary behavior affect one another? Progress in Cardiovascular Diseases. 2020.

2. Pedoman Pencegahan dan Pengendalian Coronavirus Disease (COVID-19). Jakarta: Kementerian Kesehatan Republik Indonesia, Direktorat Jenderal Pencegahan dan Pengendalian Penyakit (P2P); 2020. 1-136 p.

3. Fatoye F, Gebrye T, Odeyemi I. Real-world incidence and prevalence of low back pain using routinely collected data. Rheumatol Int 2019; 39(4): 619-26.

4. Balagué F, Mannion AF, Pellisé F, Cedraschi C. Non-specific low back pain. Lancet 2012; 379(9814): 482-91.

5. Grabovac I, Dorner TE. Association between low back pain and various everyday performances : Activities of daily living, ability to work and sexual function. Wien Klin Wochenschr 2019; 131(21-22): 541-9.

6. Fairbank JCT, Pynsent PB. The oswestry disability index. Spine 2000; 25(22).
7. Speksnijder CM, Koppenaal T, Knottnerus JA, Spigt M, Staal JB, Terwee CB. Measurement properties of the quebec back pain disability scale in patients with nonspecific low back pain: systematic review. Phys Ther 2016; 96(11): 1816-31.

8. Kopec J, Md P, Esdaile J, Md MPH, Abrahamowicz M, Abenhaim L, et al. The quebec back pain disability scale: measurement properties. Spine 1995; 20(3): 341-52.

9. Critical Appraisal Tools [Internet]. Oxford Centre for Evidence-Based Medicine. Available from: https://www.cebm.ox.ac.uk/ resources/ebm-tools/critical-appraisal-tools

10. Moher D, Liberati A, Tetzlaff J, Altman DG. Preferred reporting items for systematic reviews and meta-analyses: the PRISMA statement. PLoS Med 2009; 6(7): e1000097.

11. Fritz JM, Irrgang JJ. A comparison of a modified oswestry low back pain disability questionnaire and the quebec back pain disability scale. Phys Ther 2001; 81(2): 77688.

12. Davidson M, Keating JL. A comparison of five low back disability questionnaires: reliability and responsiveness. Phys Ther 2002; 82(1): 8-24 